\title{
MORPHOLOGICAL EFFECTS OF PACLOBUTRAZOL ON THE REGROW'TH OF REJUVENATED COFFEE (Coffea arabica L.) TREES
}

\author{
Arsenio D. Ramos ${ }^{1}$ and Antonio L. Acedo, Jr. ${ }^{2}$ \\ 'Associate Professor and Professor \\ Department of Horliculture \\ Visayas State University' Visca, Baybay' City 6521-A \\ Leyte, Pbilippines
}

\begin{abstract}
This study was conducted to determine the morphological response of the regrowth of rejuvenated coffee (Coffea arabica $\mathrm{L}$ ) to varying timing and levels of application of Paclobutrazol (PBZ) [2RS, 3RS)-1-4 (-chlorophenyl)-4,4-dimethyl-2-1, 2, 4-triazol-1-ylpenten-3-ol]. Plants applied with PBZ two months before cutting had delayed shoot emergence, were shorter and had bigger lateral branches but with comparable percent plant survival, vertical shoot stem characteristics, lateral branch morphology, leaf morphology and root volume and dry weight compared to those applied with PBZ one month before cutting. Regardless of timing of application, plants given 0.5 and $1.0 \mathrm{~g}$ a.i.PBZ $/ \mathrm{m}$ canopy span had shorter vertical shoots with shorter internodes, fewer and shorter lateral branches, smaller leaves, and bigger root volume but comparable plant survival, days to shoot emergence, vertical shoot stem diameter, number of nodes of lateral branches, number of leaves, LAI and root dry weight with the untreated plants.
\end{abstract}

Key words: Rejuvenation pruning, Paclobutrazol, Morphology, Regrowth 


\section{INTRODUCTION}

The productivity of coffee trees declines with age. Depending on the type of planting material, growing environment and cultural management adopted, coffee plants generally start producing fruits three to four years from planting. Commercial production starts six years after planting and the volume of production continues to increase until 10 years after which production starts to decline. The rate of yield decline and/or length of the productive life of the tree/plantation depend on several factors which directly or indirectly affect the yield potential of the crop. Aside from the reduction in volume of green beans, bean quality in terms of size, fat content and beverage quality have also been reported to decrease with age of the tree (Bertrand et al., 2005).

Several factors contribute to yield decline in aging coffee trees. These include reduced leaf area and inefficient light interception due to changes in growth habit (Wrigley,1988), occurrence of root dieback (Cannell, 1971a; Nutman, 1933) that may jeopardize the function of the root system, particularly uptake of nutrients from the soil (Bragança, 2005), and the increasing number of parasitic parts that could very well compete with developing flowers and fruits for carbohydrates and other nutrients required for fruit development (Cannell, 1985). These factors have been implicated in the development of more non-fruiting branches and the reduction in the number of fruits set per fruiting node (Wrigley, 1988). Hence, in the early years, coffee yield depends on the number of fruiting nodes, while in the later years, on the number of fruits set per node (Clowes, 1977).

One strategy to improve the yield of old non-productive coffee trees is rejuvenation pruning as pruning stimulates vegetative and reproductive growth (Canell, 1983; Cabangbang, 1988; CEMARRDEC, 1990; Jativa, 1990; Netsere et al., 2006; PCAR, 1977). Cabangbang (1988) reported that rejuvenated 40-year-old Robusta trees bear fruit in less than two years from pruning producing an annual yield of 1-3 tons green beans/ha out yielding the nonrejuvenated trees producing only $0.3-1.5$ tons/ha. 
Netsere et al. (2006) found that old coffee trees pruned by topping, agobiado and eskeletamento techniques, significantly out yielded the unpruned trees by $12.46,8.35$ and $4.67 \%$, respectively. Furthermore, coffee (Coffea canephora) trees pruned by stumping produced two times higher yield than the unpruned, (Jativa (1990).

An effective rejuvenation system should promote faster development of new shoot system which is required for early bearing. Components of the different rejuvenation strategies include specific cutting method (Netsere et al., 2006; Pugoy, 1991), fertilizer application (Pugoy, 1991; Bacasno, 2002), mulching (Bacasno, 2002) and shading (http://abstracts.aspb.org/pb2003/public/P72/1437). In the Philippines, rejuvenation techniques for coffee had been recommended (Cabangbang, 1990; Nestle, undated). Possible improvement of existing rejuvenation method includes the use of tree growth regulators with reinvigorating or reconditioning effect to enhance tree health.

Paclobutrazol (PBZ) [2RS, 3RS)-1-4 (-chlorophenyl)-4,4dimethyl-2-1, 2, 4-triazol-1-yl-penten-3-ol], a member of the triazole group with both fungicidal and plant growth regulatory effects, is known to have reinvigorating effect on plants by altering crop morphology including height (Berova and Zlatev, 2000; Terri and Millie, 2000; Sebastian et al. 2002; Yeshitela et al., 2004), stem diameter (Berova and Zlatev, 2000; Yelenosky et al., 1995; Jenks et al., 2001), leaf size and thickness (Sebastian et al. 2002; Yeshitela et al., 2004) and particularly improvement of fine root density (Chaney, 2005; Watson et al., 1986). To our knowledge, there has been no study which investigated the effects of pre-rejuvenation application of PBZ on the performance of rejuvenated coffee trees. Thus, this study was conducted to evaluate the effect of PBZ application on the morphology of the regrowth of the rejuvenated coffee. 


\section{MATERIALS AND METHODS}

\section{The Experimental Trees}

Thirty year-old non-productive coffee trees existing at the Coffee Project of the Department of Horticulture, College of Agriculture and Food Science, Visayas State University, Visca, Baybay City, Leyte, were used (Fig 1). The trees were planted at $3 \mathrm{~m} \times 3 \mathrm{~m}$ distance using a triangular planting system under 30-35\% shade provided by nearby Thailand acacia (Acacia spectabilis A. Cunn.ex Benth) trees. These were very tall (6.60 meters height), having an average base girth circumference of $65.52 \mathrm{~cm}$ and average canopy span of 4.20 meters. The trees had multiple vertical stems because water sprouts were not removed. The dense lateral branches found mostly at the upper part of the vertical shoots had already overlapped with the lateral branches of the neighboring trees. The fruits were few located mostly near the tip of the lateral branch. Trees with more or less the same stand (height and spread) were selected as experimental plants.

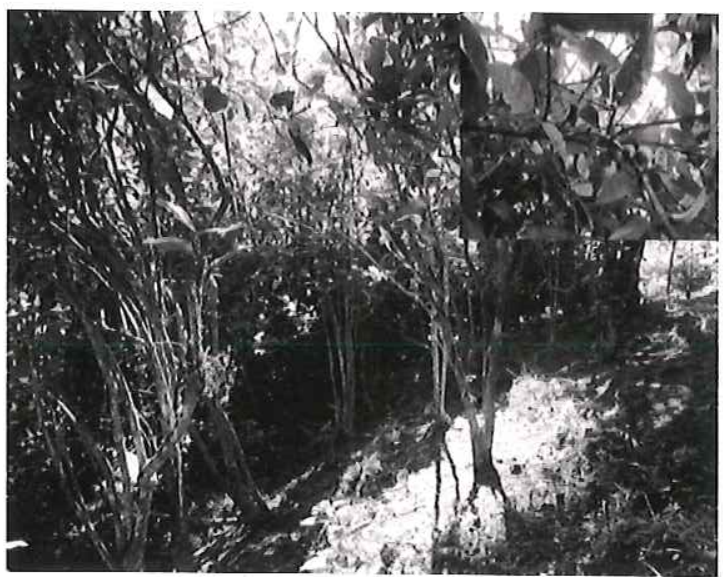

Fig.1. The experimental coffee trees prior to treatment application 


\section{Experimental Design and Treatments}

The experiment was laid out in a factorial randomized complete block design (RCBD) with three replications and three sample trees per replicate. The treatments were as follows:

Factor A (Time of PBZ application)

T1 -1 month before cutting

T2 - 2 months before cutting

Factor B (Level of PBZ application)
L1- 0 (water, control)
L2-0.5g.a.i.PBZ/meter span of canopy or $2 \mathrm{ml}$ Cultar/ meter canopy span
L3 - 1.0g.a.i.PBZ/meter span of canopy or $4 \mathrm{ml}$ Cultar/ meter canopy span

For L2 and L 3 trees, a total of 8 and $16 \mathrm{ml}$ Cultar per tree, respectively, was applied because their average canopy span was four meters.

\section{Paclobutrazol Application}

Commercial grade PBZ with $25 \%$ active ingredient (a.i.) (trade name 'Cultar 25 SC', Syngenta UK Ltd.) was used. The required amount of Cultar was dissolved in one gallon water and applied by collar drench method (Fig. 2). Furrows were dug $30 \mathrm{~cm}$ away from the tree base and the PBZ solution was applied evenly along the furrows. For the untreated control, one gallon plain tap water was applied per plant.

\section{Rejuvenation Pruning}

The procedures in heading back or rejuvenation pruning recommended by the Coffee Foundation of the Philippines Inc. (undated) was adopted. The main vertical stem was cut following a slanting cut $50 \mathrm{~cm}$ from the ground using a sharp pruning saw. The cut end was left to dry for five days and then painted with coal tar (Fig.3). 

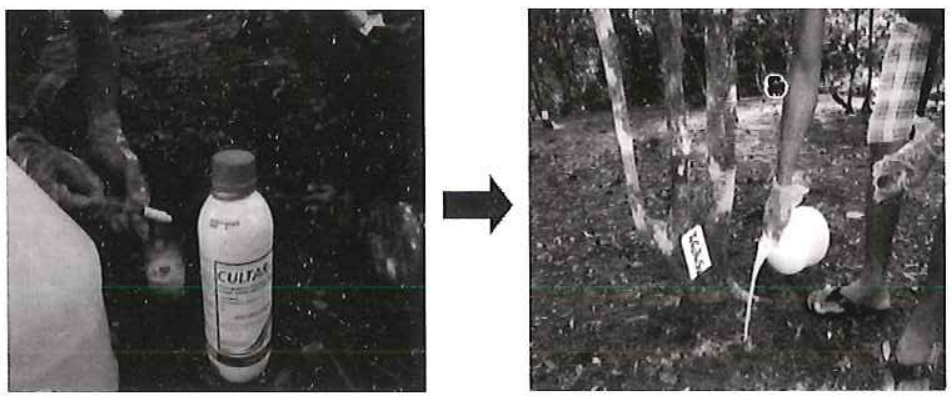

Fig.2. PBZ formulation and application by collar drenching technique
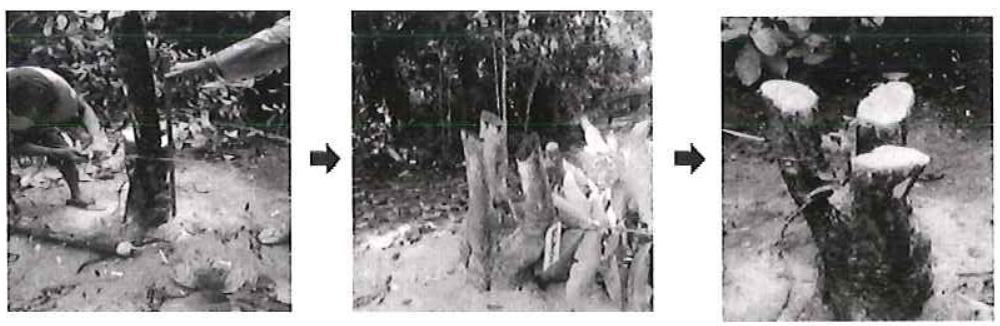

Fig 3. The rejuvenation pruning techuique for old coffee trees.

\section{Maintenance of the Experimental Trees}

The cut plants were applied with 250 grams complete fertilizer (14-14-14-14) per plant one month after pruning following the holing method (six 5-cm deep holes around the stump at a distance of $50 \mathrm{~cm}$ ). The base of the trees was ring-weeded and mulched with 5 $\mathrm{cm}$ - thick rice hull. The areas in between rows were regularly underbrushed at three- month interval.

When the sprouts were about $10 \mathrm{~cm}$ tall, the weak sprouts were removed retaining only the three most vigorous sprouts per stump. When the sprouts were about $30 \mathrm{~cm}$ in height, the two weakest sprouts were further removed retaining only the one most vigorous sprout. Three shoots (one per stump) were allowed to grow per tree 
for 10 months (Fig 4). Shoots that subsequently emerged were automatically removed.
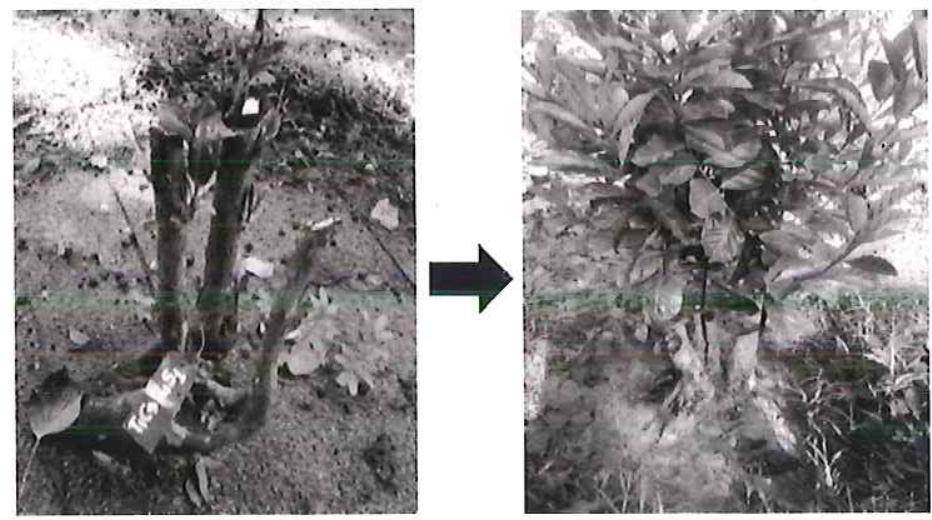

Fig 4.The selection of sprouts to establish plants with 3 shoots (1 shoot per stump)

\section{Measurement of Parameters}

Tree survival, sprout emergence, and shoot and root growth were monitored. Emergence of sprout per stump was recorded daily to get the average duration from pruning to shoot emergence. The length (from the point of attachment to the stump up to the shoot tip) and diameter (two $\mathrm{cm}$ from the point of attachment to the stump) of the stem of the vertical shoot, the length of the internode and number of lateral branches were monitored four, eight and 10 months after cutting. The length and diameter (middle of the branch) and the number of nodes of the representative pair of lateral branches (second layer from the base) were determined 10 months after cutting. Furthermore, the total number of leaves per vertical shoot, the length and width of leaves (using the 4th pair from the 1st open leaf) of the representative pair of lateral branches described above were also recorded. Plant leaf area index (LAI) was determined using a Digital Plant Canopy Imager CI-110 (CID Bio Science 1554 NE 3rd Ave. Camas, WA USA). 
Fine root (1-3 mm diameter) development was evaluated using the in-growth core technique (Person, 1983). Two opposite pits (6 $\mathrm{cm}$ diameter and $10 \mathrm{~cm}$ depth) were dug using an improvised core sampler $50 \mathrm{~cm}$ from the base of the stump. The soil clumps removed from the pits were placed in plastic bags and were brought to the laboratory for processing. The soil in each bag was cleaned of roots and other foreign matter and placed into individual containers. A fine-meshed net shaped into a receptacle was fitted into each pit and the root-free soil was poured back into the pit. To prevent possible contamination of the coffee roots with roots from adjacent plants, the base of the coffee plant (including the pit) was mulched with $5 \mathrm{~cm}$ thick rice hull. Ten months after cutting, the net containing the soil inside each pit was removed for the determination of root volume and dry weight.

\section{Statistical Analysis}

Data were analyzed by running analysis of variance (ANOVA) and treatment means were compared by Least Significant Difference (LSD) test at $5 \%$ level of significance using STAR, version 2.0.1 2014 Biometrics and Breeding Informatics, PBGB Division International Rice Research Institute, Los Banos, Laguna.

\section{RESULTS AND DISCUSSION}

\section{Plant Survival and Sprout Emergence}

Plant survival was not significantly affected by time and level of PBZ application; interaction effect was similarly not significant (Table 1). Almost all plants (92-100 percent) survived 10 months after pruning indicating that the timing and level of PBZ applied did not adversely affect coffee tree growth. Shoot development in trees applied with PBZ two months before cutting was delayed for about five days compared to those applied one month before cutting. Applying PBZ two months before pruning may have allowed the plant 
to absorb and accumulate more of it increasing its effectiveness in retarding shoot growth and hence emergence.

Table 1. Shoot emergence and plant survival of rejuvenated coffee trees as influenced by timing and levels of PBZ application

\begin{tabular}{lcc}
\hline Treatments & $\begin{array}{c}\text { Plant Survival 10 } \\
\text { Months After } \\
\text { Cutting (\%) }\end{array}$ & $\begin{array}{c}\text { Days From Cutting } \\
\text { to Shoot } \\
\text { Emergence }\end{array}$ \\
\hline Time of PBZ Application & 92.59 & $35.30 \mathrm{~b}$ \\
1 month before pruning & 100.00 & $40.19 \mathrm{a}$ \\
2 months before pruning & & \\
PBZ concentration & 100.00 & 40.89 \\
0 (water, control) & 94.44 & 36.31 \\
0.5g.a.i. PBZ/m canopy span & 94.44 & 36.53 \\
1.0g.a.i. PBZ/m canopy span & 10.23 & 11.65 \\
\hline CV (\%) & &
\end{tabular}

Mean separ ation within columns by LSD, 5\%.

\section{Shoot Morphology}

PBZ application significantly influenced shoot height, stem diameter, internode length and lateral growth (Table 2). The time of PBZ application had a significant effect on shoot height but not on stem diameter, internode length and number of lateral branches. Trees applied with PBZ one and two months before pruning were comparable in height four months after pruning. After eight months, those applied with PBZ two months before cutting were significantly shorter than those applied one month prior to pruning. After 10 months, however, a different height trend occurred. Trees treated with PBZ two months before pruning were significantly taller than those applied one month before pruning. The results indicate that the time of application of PBZ before pruning had a more pronounced effect on growth retardation. This could be related to the variations in the level of PBZ in the plant tissue (storage pool) which may be a function of the length of time the plant is absorbing the PBZ from the source (soil) and using/metabolizing it from the storage pool. Their 
comparable heights four months after cutting could be a possible result of only little variations in tissue PBZ level which could have widened on the 8th and 10 th month after pruning. The shorter plants produced when PBZ was applied two months prior to cutting was probably caused by higher level of PBZ in the plant tissue as the plants had more time to absorb the PBZ from the soil. On the 10th month after pruning, plants from trees applied with PBZ two months prior to pruning were taller than those applied with PPZ one month before pruning. This reversal of trend after 8 months of pruning could be due to lower tissue PBZ level caused by its continued metabolism. On the other hand, the taller plants after 10 months from cutting (a reversal of trend after eight months from pruning) from those applied two months prior to pruning compared to those applied one month before pruning could be due to lower-tissue PBZ level due to its continued metabolism. Lever (1986) mentioned that the ability of treated plants to outgrow the induced PGR effects is caused by triazole levels falling below a threshold.

Regardless of timing of application, the level of PBZ significantly influenced shoot length, stem diameter, internode length and number of lateral branches. After four months from pruning, trees applied with $1 \mathrm{~g}$ a.i. PBZ per meter canopy span were significantly shorter than the control and those receiving $0.5 \mathrm{~g}$ a.i. PBZ per meter canopy span. On the 10 th month, heights of those applied with 0.5 and 1.0 g.a.i. PBZ per meter canopy span were comparable and were significantly shorter than the control plants. Trees treated with 1.0 g.a.i.PBZ/ m canopy span were $25 \%$ shorter than the control trees. In terms of stem diameter, PBZ level had marked influence only after eight months from pruning. Those applied with 0.5 g.a.i. PBZ/meter canopy span were smaller than those having $1 \mathrm{~g}$ a.i. PBZ/meter canopy stand and the control. PBZ concentration likewise significantly influenced the internode length of the shoot. After eight and 10 months from pruning, PBZ-applied plants had shorter internodes than the control. As to the number of lateral branches, PBZ had marked effect on the 10th month after pruning but not on the 8th month. Plants applied with PBZ regardless of concentration had significantly fewer lateral branches than the control. 
Table 2. Vertical shoot characteristics of rejuvenated coffee trees as influenced by the timing and levels of Paclobutrazol application

\begin{tabular}{|c|c|c|c|c|c|c|c|c|c|c|}
\hline \multirow[t]{3}{*}{ Treatments } & \multicolumn{3}{|c|}{ Shool Height (cm) } & \multicolumn{3}{|c|}{$\begin{array}{l}\text { Shoot Stem Diamoter } \\
\text { (cm) }\end{array}$} & \multicolumn{2}{|c|}{ Internode Length $(\mathrm{cm})$} & \multicolumn{2}{|c|}{$\begin{array}{c}\text { Number of Lateral } \\
\text { branches/shoot }\end{array}$} \\
\hline & \multicolumn{3}{|c|}{ Month after Pruning } & \multicolumn{3}{|c|}{ Month after Pruning } & \multicolumn{2}{|c|}{ Month after Pruning } & \multicolumn{2}{|c|}{ Month after Pruning } \\
\hline & 4 & 8 & 10 & 4 & 8 & 10 & & & & 10 \\
\hline \multicolumn{11}{|l|}{ Timg of PBZ Application } \\
\hline 1 month before culting & $29.3 \mathrm{a}$ & $50.1 \mathrm{a}$ & $87.4 b$ & 0.93 & 1.38 & 2.00 & 6.30 & 9.26 & 4.4 & 13.7 \\
\hline 2 months before culting & $29.1 \mathrm{a}$ & $43.5 \mathrm{~b}$ & $99.8 \mathrm{a}$ & 0.91 & 1.33 & 1.82 & 6.03 & 10.30 & 4.6 & 125 \\
\hline \multicolumn{11}{|l|}{ PBZ Concentration } \\
\hline 0 (water, controd) & $32.3 \mathrm{a}$ & $52.4 a$ & $110.8 \mathrm{a}$ & 0.93 & $1.41 \mathrm{a}$ & 2.07 & $7.25 \mathrm{a}$ & $11.66 \mathrm{a}$ & 4.7 & $14.3 \mathrm{a}$ \\
\hline 0.5g.a.L.PBZm cancpy span & $31.9 \mathrm{a}$ & $46.8 \mathrm{ab}$ & $85.1 \mathrm{~b}$ & 0.88 & $1.26 \mathrm{~b}$ & 1.72 & $6.54 a b$ & $8.76 \mathrm{~b}$ & 4.2 & $124 \mathrm{~b}$ \\
\hline 1.0g.a.LPBZ/m canopy spal & $16.3 b$ & $40.8 b$ & $84.6 \mathrm{~b}$ & 0.95 & $1.38 \mathrm{a}$ & 1.94 & $4.78 \mathrm{~b}$ & $8.91 \mathrm{~b}$ & 4.6 & $12 \pi$ \\
\hline CV (\%) & 31.13 & 13.4 & 11.5 & 10.24 & 10.24 & 1385 & 23.62 & 10.93 & 28.2 & 9.06 \\
\hline
\end{tabular}

\section{Lateral Branch Morphology}

PBZ significantly affected the length and diameter but not the number of nodes of the lateral branches (Table 3). Plants given PBZ two months before cutting were wider/bigger but were comparable to those applied one month before pruning in terms of length and number of nodes per branch. Regardless of timing of PBZ application, lateral branches of plants applied with 0.5 and $1.0 \mathrm{~g}$ a.i. $\mathrm{PBZ} /$ meter canopy span were shorter but lateral branch diameter and number of nodes were comparable to the untreated ones. The number of nodes of the lateral branches determine the potential fruiting site (Clowes, 1977) while branch diameter determines the fruit load carrying capacity of the branch. The results indicate that PBZ treatment had positive effects on these lateral branch parameters particularly on the branch diameter. 
Table 3. Lateral branch characteristics of rejuvenated coffee trees as influenced by the timing and levels of Paclobutrazol application 10 months after cutting

\begin{tabular}{lccc}
\hline Treatments & Length (cm) & Number of Nodes & Diameter (cm) \\
\hline Time of PBZ Application & & & \\
I month before cutting & 71.12 & 6.17 & $0.743 \mathrm{~b}$ \\
2 months before cutting & 72.00 & 6.01 & $0.932 \mathrm{a}$ \\
PBZ Concentration & & & \\
0 (water, control) & $85.76 \mathrm{a}$ & 6.70 & 0.757 \\
0.5g.a.i. PBZ/m canopy span & $65.25 \mathrm{~b}$ & 5.88 & 0.847 \\
1.0g.a.i. PBZ/m canopy span & $63.68 \mathrm{~b}$ & 5.68 & 0.908 \\
\hline CV (\%) & 8.74 & 11.54 & 16.12 \\
\hline Mean separation within columns by LSD.5\%. & &
\end{tabular}

\section{Leaf Morphology}

Application of PBZ significantly influenced the length and width of leaves but not the number of leaves and leaf area index (LAI) (Table 4). Regardless of the level of PBZ, the timing of application did not significantly affect number, size and LAI. In contrast, level of PBZ applied significantly influenced leaf size but not the leaf number and the LAI. After 10 months from cutting, plants applied with the two levels of PBZ had comparable leaf lengths which were significantly shorter than the control. Plants applied with 0.5g.a.i.PBZ/meter canopy span had narrower leaves than plants applied with 1g.a.i. $\mathrm{PBZ} /$ meter canopy span and the control. Widths of leaves of plants applied with 1g.a.i. PBZ/meter canopy span were just comparable with the leaf width of the control plants. Furthermore, the level of PBZ application did not influence the LAI despite the leaf size reduction. Regardless of the level of PBZ applied, LAI at 10 months after cutting ranged from 2.5-3.3. This finding suggests that in coffee plants, the number of leaves influences LAI more than the size of the leaves.

Internode compression resulting to more compact and shorter plants is the most common effect of PBZ application (Berova and Zlatev, 2000; Terri and Millie, 2000; Sebastian et al., 2002; Yeshitela et al., 2004). Chaney (2005) stated, however, that the degree of 
shoot growth reduction is dose-sensitive and varies widely among species.

Table 4. Leaf characteristics of rejuvenated coffee trees as influenced by the timing and levels of Paclobutrazol application

\begin{tabular}{|c|c|c|c|c|c|c|c|c|c|c|}
\hline \multirow[t]{3}{*}{ Treatments } & \multirow{2}{*}{\multicolumn{3}{|c|}{$\begin{array}{c}\begin{array}{c}\text { Number of Leaves/ } \\
\text { shoot }\end{array} \\
\text { Month After Cutting }\end{array}$}} & \multirow{2}{*}{\multicolumn{3}{|c|}{$\begin{array}{c}\begin{array}{c}\text { Length of Leaves } \\
\text { (cm) }\end{array} \\
\text { Month After Cutting }\end{array}$}} & \multicolumn{3}{|c|}{ Width of Leaves $(\mathrm{cm})$} & \multirow{3}{*}{$\begin{array}{c}\text { LAI } \\
\left(10^{\text {th }}\right. \\
\text { month) }\end{array}$} \\
\hline & & & & & & & \multicolumn{3}{|c|}{ Month After Cutting } & \\
\hline & 4 & 8 & 10 & 4 & 8 & 10 & 4 & 8 & 10 & \\
\hline \multicolumn{11}{|l|}{ Time of PBZ Application } \\
\hline I month before cutting & 11.5 & 35.0 & 96.9 & 20.7 & 22.1 & 23.2 & 12.6 & 13.2 & 13.5 & 2.7 \\
\hline 2 months before cutting & 10.7 & 28.3 & 92.9 & 20.5 & 21.4 & 23.4 & 12.0 & 12.9 & 13.6 & 3.0 \\
\hline \multicolumn{11}{|l|}{ PBZ Concentration } \\
\hline 0 (water, control) & 12.8 & 34.0 & 97.5 & 22.1 & 23.0 & $25.0 \mathrm{a}$ & $12.9 \mathrm{a}$ & $13.7 \mathrm{a}$ & $14.7 \mathrm{a}$ & 3.3 \\
\hline 0.5g.a.i. PBZ/m canopy & 10.0 & 30.9 & 94.2 & 19.6 & 20.9 & $21.2 \mathrm{~b}$ & $10.9 \mathrm{~b}$ & $11.9 \mathrm{~b}$ & $12.3 b$ & 2.5 \\
\hline \multicolumn{11}{|l|}{ span } \\
\hline 1.0g.a.i. PBZ/m canopy & 10.3 & 29.9 & 93.3 & 20.2 & 21.3 & $22.2 \mathrm{~b}$ & $12.8 \mathrm{a}$ & $13.5 \mathrm{a}$ & $13.8 \mathrm{a}$ & 2.8 \\
\hline \multicolumn{11}{|l|}{ span } \\
\hline CV $(\%)$ & 17.7 & 26.0 & 11.4 & 10.2 & 8.5 & 9.8 & 7.9 & 7.4 & 6.3 & 25.6 \\
\hline
\end{tabular}

Mean separation within columms by LSD, 5\%.

\section{Root Morphology}

PBZ application time had no significant effect on root dry weight. Similarly, PBZ concentration did not affect both root volume and dry weight (Table 5). However, PBZ concentration remarkably affected root volume. Plants applied with 0.5-1.0 ga.i.PBZ had higher root volume than the control, which was due to the production of more fine roots (Fig. 5). This could be a result of increased assimilate partitioning to the roots. . Chaney (2005) mentioned that usually the response in PBZ-treated trees was an increase in root to shoot ratio. Watson (2003), as cited by Chaney (2005), found that soil injection of PBZ around the trunk base of white and pink oaks produced a root mass $60-80 \%$ higher near the base than that of the untreated trees. 
Table 5. Root production of rejuvenated coffee trees as influenced by the timing and levels of Paclobutrazol application 10 months after cutting

\begin{tabular}{lcc}
\hline Treatments & $\begin{array}{c}\text { Root Dry Weight } \\
\left(\mathbf{m g} / 283 \mathbf{c m}^{3} \text { soil) }\right.\end{array}$ & $\begin{array}{c}\text { Root volume } \\
\left(\mathbf{m l} / 283 \mathrm{~cm}^{3} \mathbf{~ s o i l )}\right)\end{array}$ \\
\hline Time of PBZ Application & 1.89 & 1.16 \\
1 month before cutting & 2.44 & 1.40 \\
2 months before cutting & & \\
PBZ Concentration & 1.94 & $0.90 \mathrm{~b}$ \\
0 (water, control) & 2.43 & $1.51 \mathrm{a}$ \\
0.5g.a.i. PBZ/m canopy span & 2.12 & $1.44 \mathrm{a}$ \\
1.0g.a.i. PBZ/m canopy span & 33.8 & 17.38 \\
\hline CV (\%) & &
\end{tabular}

Mean separation within columns by LSD, 5\%.
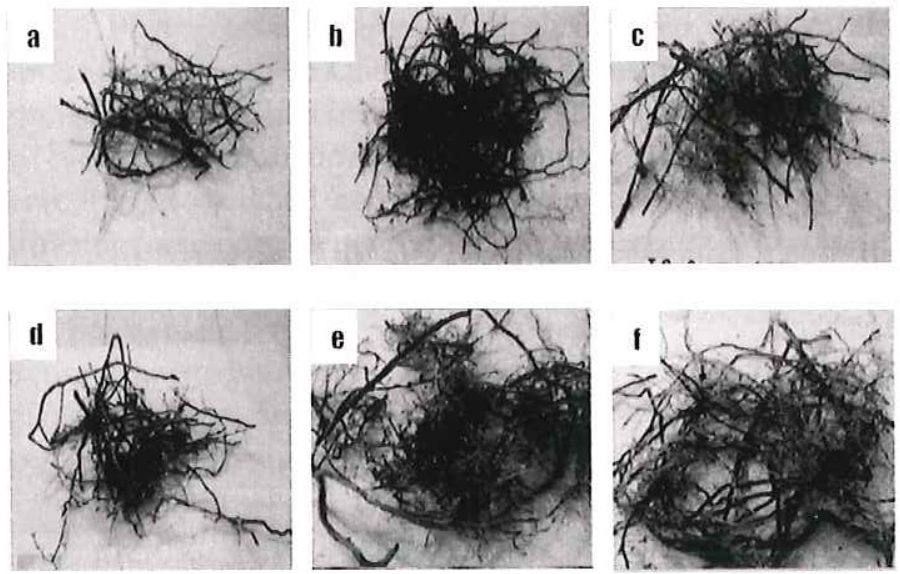

Fig.5. Fine root production of rejuvenated coffee trees applied with 0 g.a.i.PBZ (a), 0.5 g.a.i.PBZ (b) and $1.0 \mathrm{~g}$ a.i. PBZ (c) per meter canopy span 1 month before cutting and trees applied with $0 \mathrm{~g}$ a.i.PBZ (d), $0.5 \mathrm{~g}$ a.i.PBZ (e) and $1.0 \mathrm{~g}$ a.i. $\mathrm{PBZ}$ (f) per meter canopy span 2 months before cutting. 
In rice seedlings, Yim et al. (1997) found that PBZ increased root dry mass and their ability to produce new roots. Davis et al. (1985) observed that adventitious root formation was promoted by PBZ in bean hypocotyl cuttings. Symons et al. (1990) attributed the improved rooting to increased assimilate partitioning to the roots due to reduced demand in the shoots. In white and pink oak, Watson (1986) attributed the increase in root densities as either a direct effect of PBZ on root growth or just an indirect effect resulting from shoot growth modification and a shift in carbohydrate allocation to the roots.

\section{CONCLUSION}

Pre-rejuvenation application of Paclobutrazol significantly altered some morphological features of the coffee (C. arabica) regrowth. PBZ treatment produced shorter coffee trees having shorter compressed internodes, slightly smaller vertical stems, smaller leaves but with LAI comparable to those of the control, shorter but bigger lateral branches and produced more fine roots. The extent of PBZ effect on coffee morphology is influenced both by time and level of application.

\section{LITERATURE CITED}

BACASNO, W. C. 2002. Effects of mulching and fertilizer application on the early growth performance of rejuvenated coffee trees (Coffea arabica L.).Undergraduate BSA thesis. Leyte State University, Visca, Baybay, Leyte. 43 pp.

BAS, 2013. Bureau of Agricultural Statistics http://countrystat.bas.gov.ph/

BERTRAND, B., H. ETIENNE, B. GUYOT, and P. VAAST. 2005. Year of production and canopy region influence bean characteristics and beverage quality of Arabica coffee. Paper presented in the 20th International Conference on Coffee Science, October 11-15, 2005, Bangalore, India. 
BEROVA, M and Z. ZLATEV. 2000. Physiological response and yield of paclobutrazol treated tomato (Lycopersicon esculentum Mill). Plant Growth regulator 30,(2)117-123

BRAGANÇA, S.M. 2005. Crescimento e acúmulo de nutrientespelocafeeiroconilon (Coffea canephora Pierre).Viçosa, Universidade Federal de Viçosa.Ph.D.thesis.

CABANGBANG, R. P. 1990. Coffee Rejuvenation in the Philippines. Technol.J., 12(3):1-16.

CANNELL, M.G. 1985. Physiology of the coffee crop. In: Clifford, M.N. and K.C. Willson (eds), Coffee - Botany, Biochemistry and Production of Beans and Beverage. London: Crom Helm. pp. 108-134.

CANNELL, M.G. 1971. Effects of fruiting, defoliation and ringbarking on the accumulation and distribution of dry matter in branches of Coffea arabica L. Kenya Exp. Agric. 7:53-74.

CEMARRDEC. 1990. Mga tanong at sagot tukol sa pagpapabata ng kape. Kabakan, Cotabato: University of Southern Mindanao. 12p.

CHANEY, W.R. 2005. Growth retardants: A promising tool for managing urban trees. Purdue University Extension. FNR-252-W.

CLOWES, M.S.J. 1977.A study of the growth of the Coffea arabica L. fruits in Rhodesia. Rhodesia J. Agric. Res. 15:89-93.

COFFEE FOUNDATION OF THE PHILIPPINES INC (undated).Coffee Rejuvenation.11 pp.

DAVIS, T.D., G.L. STEFFENS, and N. SANKLA. 1988. Triazole plant growth regulators. Hort. Rev. 10:63-105.

JATIVA, M. 1990. Rehabilitation of coffee trees by stumping in the Amazone Region, Ecuador.Boletin Divulgativo INIAP 1990 No. 207.9p. 
JENKS, M. A., L. ANDERSONT, R.S EUSINK, and M.H. WILLIAMS. 2001. Leaf cuticular waxes of potted roses cultivars as affected by plant development, drought and paclobutrazol treatments. Physiol. Plant. 112:62-70.

LEVER,B.G. 1986. 'Cultar' A technical overview. Acta Hortic. 179:459-466.

Lichtenthaler, H.K., Schwender, J. and Rohner, M. 1997. Two independent biochernical pathways for isopentyldiphosphateandisoprenoid biosynthesis in higher plants. Physiol. Plant. 101: 643452.

NESTLE' TRAINING GUIDE (undated). And Kape nga Putlonon.11 pp.

NETSERE, A., T. SHIMBER, T. KUFA, E. TAYE, and W. GEBRESELASSIE. 2006. Yield response of forest arabica coffee to ridges and rejuvenation methods. Paper presented in the 21st International Conference on Coffee Science, September 11-15, 2006, Montpellier, France. pp. 1101-1105.

NUTMAN, F.J. 1933. The root system of Coffea arabica L. I. Root systems in typical soils of British East Africa. Empire J. Expl. Agric. 1:271-284.

PCAR, 1977.The Philippines Recommends for Coffee. Phil. Coun. for Agric. and Res. UPLB College of Agriculture, Los Banos, Laguna. $49 \mathrm{pp}$.

PERSON, H.A.1983. The distribution and productivity of fine roots in boreal forest. Plant and Soil 71:87-101

PUGOY, N.P. 1991. Initial vegetative regeneration of rejuvenated coffee is influenced by cutting height and NPK fertilizer combination scheme. Undergraduate BSA Thesis.ViSCA, Baybay, Leyte. 52 pp. 
SEBASTIAN, B.G., G. ALBERTO, A.C. EMELIO, A.F. JOSE, and A.F. JUAN. 2002. Growth development and color response of potted Dianthus caryophyllus cv. Mandarin to Paclobutrazol treatment. Sci. Hort. 1767, 1-7.

SYMONS, P.R.R., P. J. HOFMAN, and B.N. WOLSTENHOLME. 1990. Responses to paclobutrazol of potted "Haas" avocado trees. Acta.Hort. 275.193-198.

TERRI, W.S. and S.W. MILLIE. 2000. Growth retardants affect growth and flowering of Scaeuela. Hort. Sci. 35(1):36-38.

WATSON.G.W. 1986.Tree root system enhancement with paclobutrazol. Jour. Arboriculture 22(5):211-216.

WRIGLEY, G. 1988. Coffee. Harlow Longman Sci. and Tech. England.639 pp.

YELENOSKY, G., J.C.V. VU, and H.K. WUTCHER. 1995. Ifluence of paclobutrazol in the soil on growth, nutrient elements in the leaves and flood/freeze tolerance of citrus rootstocks seedlings. J. Plant Growth Regul. 14:129-134

YESHITELA, T.B. 2004. Paclobutrazol suppressed vegetative growth and improved yield as well as fruit quality of 'Tommy Atkins' mango (Mangifera indica L.) in Ethiopia. New Zealand Jour. of Crop and Horticultural Sci. 32(3).The Royal Society of New Zealand.

YIM, K.O., Y.W. UWON, and D.E. BAYER.1997. Growth responses and allocation of assimilates in rice seedlings by paclobutrazol and gibberellin treatment. J. Plant Growth Regul. 16:35-41. 